Kadar Garam Putih dan Kuning Telur.

Pada tabel 2 dapat dilihat kadar garam putih dan kuning telur asin selama penyimpanan. Kadar garam putih telur lebih tinggi dibanding dengan kuning telur. Pada waktu penyimpanan, kadar garam dalam putih telur semakin menurun, sedangkan kadar garam kuning telur semakin naik. Hal ini menunjukkan bahwa selama penyimpanan terjadi difusi garam dapur dari putih telur kearah kuning telur sampai kadar garam sama rata diseluruh permukaan (Suhendra, L. 1976). Keadaan ini berlangsung pada semua perlakuan. Namun kadar garam pada perlakuan $\mathrm{A}_{3}$ menunjukkan yang paling rendah, hal ini dapat terjadi karena proses difusi garam dapur terlambat karena perendaman telur pada larutan teh dilakukan sebelum pengasinan, yang merubah sifat kulit telur menjadi impermiabel.

\section{DAFTAR PUSTAKA}

Frazier, W.C. and D.C. Westhoff. 1979. Food Mikrobiology. McGraw-Hill Inc.. New York.
Gustavson, K.H. 1956. The Chemistry of Tanning Processes. Academic Press. Inc. Publishers, New York.

O'Flaherty, W.T.R. 1958, The Chemistry and Technology of Leather 2. Reinkold Publishing Coorp, New. York.

Robinson, D.W. et al. 1977. Berita P4T. Pusat Pengembangan Penelitian Peternakan, Ciawi.

Romanoff, A.L. and A.J. Romanoff, 1949. The Avian Egg. Jhon Wiley and Sons, Inc. New York.

Sirait, c.S. 1983. Hubungan Warna dan Mutu Telur. Poultry Indonesia. No. 44/Th IV : 14.

Soekarto, S.T. 1981. Penilaian Organoleptik. Prisbangtepa. Institut Pertanian Bogor, Bogor.

Stadelman, W.J. and O.J. Cotterill. 1973. Egg Science and Technology. The Avi Publishing Company, Inc Connecticut.

Stell, R.G.D. and J.H. Torrie. 1960. Principles and Procedures of Statistics. McGraw - Hill Book Co., New York.

Suhendra, L. 1976. Pengaruh Cara Pengasinan Telur Bebek (Muscovy sp.) dengan menggunakan Adonan Campuran Garam dan Bata. terhadap Mutu Telur Asin Selama Penyimpanan. Thesis Sarjana Teknologi Hasil Pertanian FATEMETA - IPB, Bogor.

\title{
PEMANFAATAN DAGING ITIK PETELUR AFKIR DI DAERAH ISTIMEWA YOGYAKARTA DAN BALI
}

Triyantini, R. Sunarlim, Abubakar *)

\begin{abstract}
ABSTRAK
Itik petelur yang sudah diafkir masih dapat dimanfaatkan sebagai sumber daging. Populasi itik petelur di Indonesia cukup tinggi sehingga cukup berpotensi dalam mensuplai kebutuhan daging dalam negeri. Tetapi potensi ini belum banyak dimanfaatkan oleh masyarakat, karena daging itik belum memasyarakat seperti daging ayam. Untuk memperoleh informasi tentang pemanfaatan dan pengolahan daging itik petelur afkir secara tradisional, telah
\end{abstract}

") Balai Penelitian Ternak, Ciawi - Bogor. dilakukan survai di D.I. Yogyakarta dan Bali. Dari hasil survai diperoleh informasi bahwa di daerah Sleman (D.I.Y.) terdapat 8 orang pengolah daging itik yang usahanya sudah berjalan terus-menerus. Hasil olahan disebut opor, berwarna coklat dan tahan disimpan sampai 2 hari. Pemasaran hasil olahan ini baru mencapai sekitar daerah Sleman. Sedangkan di daerah Gianyar (Bali) ada 3 orang pengolah betutu, usahanya masih bersifat musiman. Hasil olahan berwarna kuning. mempunyai daya tahan 3 hari. Pemasarannya adalah rumah makan, hotel atau perorangan, berdasarkan pesanan. Pengolahan sudah sedikit mengarah ke pengawetan, karena adanya unsur pemanggang dan pengasapan. Pengolahan secara tradisional ini dapat dikembangkan untuk menunjang pemasyarakatan daging itik. 


\section{PENDAHULUAN}

Itik, termasuk unggas yang mempunyai siklus reproduksi relatif singkat. Ternak ini sudah lama dikenal dan dibudidayakan oleh para petani di daerah persawahan, tepi pantai dan rawa-rawa. Sistim pemeliharaan pada umumnya secara tradisional dan terpadu dengan pertanian (Siregar, 1979; Siregar, 1982).

Di Indonesia, selama ini itik diternakkan sebagai petelur, sedang itik pedaging belum populer. Itik petelur yang siafkir masih dapat dimanfaatkan sebagai sumber daging seperti halnya ayam petelur. Oleh karena itu, itik berpotensi tinggi dalam menunjang usaha peningkatan gizi masyarakat terutama yang tinggal di pedesaan, karena ternak itik pada umumnya terdapat di pedesaan dan harga itik petelur afkir relatif lebih murah dibanding ayam (Siregar, 1980; Siregar, 1981). Daging itik belum populer seperti daging ayam, sehingga konsumennya masih terbatas. $\mathrm{Hal}$ ini disebabkan karena sebagian besar masyarakat beranggapan bahwa bau daging itik, kurang disukai. Sebagai akibat dari adanya faktor pembatas tersebut, potensi itik sebagai pensuplai daging belum banyak termanfaatkan. Keadaan ini sebenarnya dapat dipecahkan dengan cara pengolahan tertentu, misalnya di daerah Hulu Sungai Utara, daging itik dibuat dendeng yang berbentuk bundar, berminyak, berwarna kehitaman dan mempunyai aroma spesifik (Sunarlim, 1984).

Untuk mengetahui seberapa jauh daging itik peteiur afkir sudah dimanfaatkan oleh masyarakat dan cara-cara pengolahannya secara tradisional, perlu dilakukan survai ke daerah-daerah pusat peternakan itik. Hasil yang diperoleh di harapkan dapat dikembangkan dan disebarluaskan ke daerah-daerah lain untuk menunjang pemanfaatan daging itik petelur afkir.

\section{MATERI DAN METODA}

Untuk memperoleh informasi tentang pengolahan secara tradisional daging itik petelur afkir dan pemanfaatannya, telah dilakukan survai di Daerah Istimewa Yogyakarta (D.I.Y.) dan Bali. Yang dimaksud dengan itik petelur afkir adalah itik betina yang produksinya rendah, itik betina yang sudah tua, itik betina yang cacat dan itik jantan. Pemilihan lokasi berdasarkan jumlah populasi itik (diambil populasi yang tinggi) dan lokasi survai tersebut terdapat pengolahan daging itik. Lokasi survai adalah kabupaten Sleman, Bantul dan Kulon Progo untuk D.I.Y., sedang untuk daerah Bali adalah kabupaten Gianyar, Tabanan dan Badung. Pemilihan responden dilakukan secara acak sederhana (semua pengolahan diambil sebagai responden).

Responden terdiri dari :

8 pengolah daging itik di D.I.Y.

3 pengolah daging itik di Bali dan

30 peternak dari masing-masing daerah.
Infomrasi diperoleh dengan mengadakan wawancara kepada responden, berpedoman pada daftar pertanyaan yang telah disiapkan.

\section{HASIL DAN PEMBAHASAN}

Pengolahan Daging Itik.

Di daerah Istimewa Yogyakarta, pengolah daging itik terdapat di kabupaten Sleman. Hasil olahannya adalah opor yang berwarna coklat tua dan tahandisimpan sampai 2 hari. Usaha pengolahan ini dikerjakan secara tradisional, bersifat terus-menerus dan merupakan pekerjaan sambilan di samping bertani yang lebih bertujuan untuk menambah penghasilan. Sebagian besar dari pengolah $(+62,5 \%)$ berpendidikan Sekolah Dasar dan sisanya tidak bersekolah. Pengetahuan tentang cara mengolah daging itik diperoleh secara turun-temurun dengan pengalaman paling sedikit 5 tahun. Daging itik yang diolah berasal dari itik petelur afkir yang dibeli dalam keadaan hidup di pasar atau dari peternak di sekitar tempat tinggalnya. Hasil olahan dipasarkan di rumah atau di pasar, dan baru menjangkau daerah sekitarnya.

Cara péngolahan adalah sebagai berikut :

Bumbu-bumbu: bawang putih, bawang merah, ketumbar, gula merah, garam, sereh, jahe, lengkuas, semua dihaluskan. Jumlah tiap-tiap jenis bumbu hanya berdasarkan perkiraan. Karkas itik dipotong-potong seperti cara pemotongan karkas ayam. Potongan-potongan daging itik direbus bersama bumbu sampai empuk, kemudian ditambahkan santan. Perebusan diteruskan sampai kering yang memakan waktu lebih kurang 2 jam.

Hasil olahan ini berwarna coklat tua, mempunyai aroma seperti daging asap. Diduga aroma ini adalah akibat dari perlakuan pembakaran bulu-bulu halus dalam proses pembuangan bulu. Bahan bakar yang digunakan adalah jerami padi yang banyak menghasilkan asap dan asap inilah yang meresap ke dalam daging sehingga menimbulkan aroma yang khas. Hal ini sesuai dengan laporan Adnan (1977) yang menyebutkan bahwa pengasapan daging akan menghasilkan daging asap dengan aroma khas.

Di daerah Bali, pengolah daging itik dapat dijumpai di daerah Gianyar. Hasil olahannya disebut betutu. Betutu berwarna kuning, di bungkus pelepah pinang, dan tahan disimpan sampai 3 hari. Usaha pengolahan bersifat musiman, betutu diolah bila ada pesanan. Pemesan biasanya adalah rumah makan, hotel atau perorangan; bahkan olahan ada yang di bawa ke Jakarta. Semua pengolah di daerah Gianyar tidak bersekolah, pengetahuan tentang cara mengolah diperoleh secara turun-temurun dengan pengalaman paling sedikit 5 tahun.

Meskipun berdasarkan pesanan, pengolahan dilakukan hampir setiap hari karena selalu ada pesanan. Daging itik yang diolah dibeli dalam keadaan hidup, dari peternak di sekitar tempat tinggalnya. Rata-rata tiap hari memotong 3-5 ekor itik. 
Cara mengolah betutu adalah sebagai berikut:

Bumbu-bumbu: bawang merah, bawang putih, cabe, merica, asam, terasi, gula merah, garam, pala, kunyit, jahe kencur, lengkuas, semua dihaluskan. Perbandingan antara tiap jenis bumbu hanya berdasarkan perkiraan. Daging itik yang sudah bersih dibiarkan utuh, kemudian dilumuri terasi dan asam yang sudah dicampur dengan minyak goreng, kemudian dipijit-pijit selama lebih kurang 10 menit. Bumbu yang sudah halus dimasukkan ke dalam rongga badan, ditambah $250 \mathrm{ml}$ air. Karkas yang sudah diisi bumbu dibungkus dengan pelepah pinang sebanyak 3 lapis dan diikat dengan tali dari bambu; kemudian dibakar dalam timbunan sekam pada selama lebih kurang 12 jam.

Sama dengan di Yogyakarta, pembuangań bulu-bulu halus dilakukan dengan cara pembakaran. Sehingga dalam pembuatan betutu, selain dipanggang juga ada unsur pengasapan. Pelepah pinang yang digunakan sebagai pembungkus betutu, diduga mengandung tanin yang merupakan bahan pengawet meskipun konsentrasinya kecil.

\section{Konsumen daging itik.}

Konsumen daging itik masih terbatas yakni, masyarakat disekitar pengolah dan peternak itik. Pengolah daging itik di D.I. Yogyakarta mengkonsumsi hasil olahan yang tidak terjual. Peternak itik di D.I. Yogyakarta pada umumnya sudah mengkonsumsi daging itik untuk keluarganya, tetapi masih terbatas pada waktu-waktu tertentu, yaitu bila ada itik yang sakit atau cacat. Pemasaran itik petelur afkir sebagian besar ke daerah Sleman. Itik-itik ini dipasarkan dalam keadaan hidup.

Di Daerah Bali, baik pengolah maupun peternak sudah biasa mengkonsumsi daging itik yaitu setiap melakukan upacara adat. Tetapi yang biasa di konsumsi adalah jenis itik khusus untuk upacara, bukan itik petelur afkir. Pemasaran itik petelur afkir adalah ke daerah Jawa.

\section{KESIMPULAN}

Dari hasil survai ini dapat diambil kesimpulan bahwa di D.I. Yogyakarta, daging itik diolah secara tradisional menjadi opor, sedangkan di daera Bali daging itik diolah menjadi betutu, masing-masing olahan tahan disimpan 2 dan 3 hari. Itik petelur afkir dipasarkan dalam bentuk karkas. sedangkan pemasaran hasil olahan masih terbatas di daerah sekitar pengolah dan peternak itik.

\section{DAFTAR PUSTAKA}

Adnan, A.S., 1977. Tinjauan Umum Tentang Daging Dan Masalahnya. Lembaga Penelitian Peternakan Bogor.

Siregar, A.P., 1979. Duck Nutrition. Proceedings Second Poultry Science and-Industry Seminar, P3T. Ciawi Bogor.

-.-- 1980. Pengembangan Teknologi Pemeliharaan Itik Untuk Memanfaatkan Sumber Daya Pedesaan. Poultry Indonesia No. : 11. Th. 1980.

_._. 1981. Membangun Industry Perunggasan Indonesia Poultry Indonesia No: 16. Tn. 1981.

--- 1982. Ternak Itik Asset Nasional Yang Dilupakan Poultry Indonesia No : 26. Th. 1982.

Sunarlim, R., 1984. Evaluasi uji kebusukan telur dan dendeng itik yang diperoleh dari hulu Sungar Utara, Kalimantan Selatan; Wartazoa Vol 1, No. 3 Januart 1984. Pusat Penelitian dan Pengembangan Peternakan, Bogor. 